Institute for Research on Poverty

Discussion Paper no. 1040-94

\title{
Taxes and the Poor: A Microsimulation Study of Implicit and Explicit Taxes
}

\author{
Stacy Dickert \\ Scott Houser \\ John Karl Scholz \\ Department of Economics \\ Institute for Research on Poverty \\ University of Wisconsin-Madison
}

August 1994

This paper was prepared for the National Tax Association Spring Symposium. This project was funded in part through Grant Number 59-3198-3-073 from the Food and Nutrition Service, U.S. Department of Agriculture. We also gratefully acknowledge support from the U.S. Bureau of the Census and the Department of Health and Human Services, Office of the Assistant Secretary for Planning and Evaluation, and helpful comments from Tom Bowne and Elizabeth Evanson. The opinions and conclusions expressed in this paper do not necessarily reflect the views of any of the sponsoring organizations. 


\begin{abstract}
The authors measure the cumulative burden on low-income households resulting from explicit taxes (state and federal income, and payroll taxes) and implicit taxes (reductions of program benefits as earnings rise). With monthly data from the 1990 Survey of Income and Program Participation, a simulation model calculates the benefits and taxes households receive and pay in 1990. A household's marginal tax rate is established by simulating the benefits and taxes the household would receive and pay if each member aged 15 or more received additional earnings of $\$ 10$ per month. The changes in income that would result if all household members age 15 or older took a half-time, minimum-wage job are also calculated.

Typical cumulative marginal tax rates on poor households are found to be about 27 percent, but this masks considerable variation across states as a result of differences in program eligibility rules, state income taxes, and state AFDC policies. The tax burdens resulting from taking a half-time minimum-wage job also vary greatly across states, and participants in AFDC and food stamps face median marginal tax rates significantly above the rates for all poor households. A consistent result, however, is that typical tax rates on the poor rarely exceed 60 percent when income changes resulting from incremental changes in monthly earnings are calculated. The authors conclude that for most poor households, tax rates are not so high as to diminish the possible effectiveness of such policies as the Earned Income Tax Credit, which try to make work more attractive than welfare.
\end{abstract}




\section{Taxes and the Poor: A Microsimulation Study of Implicit and Explicit Taxes}

Low-income households may pay a variety of explicit taxes on earnings. Benefits from income transfer programs may also fall with earnings, imposing implicit taxes. The cumulative burden of explicit and implicit taxes can be severe. For example, a household with one parent, two children, and earned income of $\$ 16,050$ in 1994 will face the following combination of taxes: a combined employee and employer share of payroll taxes of 15.3 percent, a 15 percent federal marginal tax rate, a 17.7 percent benefit reduction rate on the earned income tax credit, and possibly state income taxes. For households that are typically poorer than this, the Aid to Families with Dependent Children program (AFDC) imposes a 662/3 percent benefit reduction rate on earnings that exceed "disregards" (described below) in the first four months of work; after four months the rate is 100 percent. The food stamp program imposes a 30 percent benefit reduction rate on "countable" income, and the Supplemental Security Income program (SSI) imposes a 50 percent benefit reduction rate on earnings that exceed disregards.

In this paper we measure the cumulative burden of explicit and implicit taxes faced by lowincome households. Two issues motivate the analysis. First, a central part of the Clinton administration's welfare reform strategy is to reduce reliance on welfare by "making work pay." The large increase in the EITC, implemented as part of the 1993 budget legislation, is intended to meet this goal (see Scholz, 1994, and Yin et al., 1994 for detailed discussions of the EITC). If the cumulative tax burdens faced by the poor are very high, however, even the 40 percent wage subsidy that the EITC will offer to low-income taxpayers with two or more children may not be enough to make work an economically attractive option relative to welfare. Put differently, if taking a job leads to little or no additional after-tax and after-transfer income, a "make work pay" strategy of welfare reform is unlikely to be successful. Second, careful measurement of cumulative tax burdens is the first step toward examining the effects of taxation on economic behavior, such as labor supply. Because of cross- 
sectional variation in AFDC program rules and state income taxes, the tax treatment of otherwise identical households may differ significantly depending on their state of residence. If taxes affect the labor market behavior of low-income households, we can exploit this cross-state variation to examine the effect of taxes. Before doing so, however, we need to carefully characterize these tax rates.

To examine cumulative tax rates on low-income households, we developed a simulation model that uses monthly data for the 1990 calendar year drawn from the 1990 Survey of Income and Program Participation (SIPP). The model is coded in the computer language C, runs on a personal computer, and contains detailed modules for SSI, AFDC, food stamps, federal income taxes, state income taxes, and payroll taxes. The model calculates the benefits and taxes households receive and pay in 1990. We then simulate the benefits and taxes the household would receive and pay if each member of the household age 15 or older receives additional earnings of $\$ 10$ per month. The change in after-tax, after-transfer income divided by the incremental income received by the household is a measure of the household's marginal tax rate. From the perspective of welfare reform, however, the interesting question is often not what is the marginal tax rate on incremental earnings, but rather, what would be the change in consumable income if household members take new jobs? Therefore, we also examine changes in after-tax, after-transfer income that would result if all household members age 15 or older take a half-time minimum-wage job.

We find that the poor often face high marginal tax rates, in many cases even higher than those faced by wealthy taxpayers. We also find, however, that the highest rates faced by the poor rarely exceed 60 percent (and are generally substantially lower), which makes it possible for the EITC to have a beneficial effect on labor supply. If we had found effective tax rates approaching or exceeding 100 percent, the effect of the EITC on the labor market behavior of the poor would not be an interesting question because work would not be sufficiently more attractive than welfare. Instead, we find the mean marginal tax rate on an AFDC recipient who takes a half-time minimum-wage job to be 
51.6 percent in 1990. By 1996 (when the EITC expansion is fully phased in) this effective tax rate will be 20 percentage points lower for a family with one child and 26 percentage points lower for a family with two or more children. ${ }^{1}$ The degree to which people will respond to this change in incentives remains an open question, but a reduction in marginal tax rates from, say, 52 percent to 26 percent may have a noticeable effect on the labor market behavior of low-income households. The model and the results reported in this paper take a first step toward a more detailed look at the effects of taxes on the labor market behavior of the poor.

\section{BACKGROUND LITERATURE}

No study examines the combined burden of implicit and explicit taxes borne by low-income households. Several papers regress AFDC benefits on variables that determine benefits, using AFDC administrative data to examine marginal tax rates imposed by AFDC. Lurie (1974), for example, used a 1971 survey of AFDC families and found the average effective tax rates on earnings were 0 to 41 percent. These rates were well below the statutory marginal tax rate of 67 percent, because some earnings are not included in the income base subject to tax; for example, deductions-termed disregards - are allowed for child care expenses, work expenses, and a general exemption. Also, some income sources may be underreported by recipients and ignored by caseworkers (see Edin and Jencks, 1992). Lurie's estimate of the effective implicit tax on unearned income ranged from 59 to 95 percent.

Hutchens (1978), using administrative data from 20 states, modeled the effect of disregards, accounting in his regression framework for truncation that arises in samples of AFDC recipients. He found the average effective tax rate from AFDC was 64.6 percent in 1967. Between 1967 and 1971

\footnotetext{
${ }^{1}$ The EITC subsidy rate was 14 percent in 1990. In 1996 the subsidy rate will be 34 percent for one-child families and 40 percent for families with two or more children.
} 
the statutory marginal tax rate on earnings in excess of disregards fell to 67 percent from 100 percent. Hutchens estimated that this caused the average effective tax rate to fall to 36.8 percent by 1971 . He also found wide variation in tax rates across states, ranging from 16.6 percent in California to 58.3 percent in Michigan.

Moffitt (1979) examined administrative data from AFDC and food stamp offices in Gary, Indiana. After accounting for disregards associated with AFDC and food stamps, he found the average effective tax rate of 38 percent on AFDC and food stamp recipients to be significantly below the average statutory marginal tax rate of 57 percent. Moffitt suggested that due to administrative error and discretion, actual AFDC and food stamp benefits may be as much as one-third lower than the amount recipients were entitled to receive.

Fraker, Moffitt, and Wolf (1985) analyzed repeated cross sections of AFDC administrative data from 1967 to 1982. They found that effective AFDC tax rates on earned income fell from 32 percent to 16 percent between 1967 and 1971 and rose throughout the 1970s. By 1979 the 28 percent effective tax rate was near its 1967 level. In 1981 the statutory tax rate on earned income after disregards was raised to 100 percent from 67 percent, subject to the "30 and one-third" provision that allows an AFDC recipient to keep $\$ 30$ and one-third of earned income for the first four months of work. Fraker, Moffitt, and Wolf found that the effective tax rate rose 22 to 46 percent by 1982 for those no longer receiving the $\$ 30$ and one-third deduction, though the authors noted that the estimates were based on quite small samples. For those still receiving the $\$ 30$ and one-third deduction, the tax rate rose 15 to 21 percent as a result of 1981 restrictions on child care and work expense deductions. ${ }^{2}$

\footnotetext{
${ }^{2}$ Other tax rate studies include Heffernan (1973), who examined marginal tax rates on AFDC using a 1970 administrative sample of Aid to Needy Families with Children in Vermont. A related literature examines the ability of multiple programs to close the poverty gap, and in so doing, describes statutory rules affecting program eligibility and benefits (see, for example, Weinberg, 1985 and 1987; and MacDonald, 1985). The literature on the effects of multiple programs and labor supply examines behavioral responses to taxation (see, for example Fraker and Moffitt, 1988; Moffitt and Wolfe, 1992; Keane and Moffitt, 1991; and Hoynes, 1993).
} 
A second branch of literature uses microsimulation models to calculate tax burdens on lowincome households. Chernick and Reschovsky's (1990) model was developed to examine explicit tax burdens imposed by federal and state income taxes, property taxes, and sales taxes on low-income households in Massachusetts and New York. They calculated that average tax burdens on poor families and individuals in 1988 were 15.3 percent in Massachusetts and 18 percent in New York. Most of this burden was generated by state and local taxes. As the sales and property tax tend to be relatively uniform, the average tax rates calculated by Chernick and Reschovsky probably do not differ greatly from the marginal explicit rates borne by taxpayers.

Our work combines elements of both strands of literature. We use a nationally representative sample with monthly data on households and model detail of tax and transfer programs. Hence we estimate implicit taxes for income transfer programs and explicit taxes paid by households.

\section{EXPLICIT AND IMPLICIT TAXES AND THE POOR}

Reducing marginal tax burdens on low-income households has been a central concern of past welfare reforms. The 1967 amendments to the Social Security Act exempted the first $\$ 30$ of earnings of AFDC recipients and lowered the benefit reduction rate to 67 percent from 100 percent with the explicit aim of making work profitable for welfare participants in all states. The Family Assistance Plan, President Nixon's negative income tax proposal, had a marginal tax rate of 50 percent. $^{3}$

President Carter's welfare reform proposal, the Program for Better Jobs and Income, included different marginal tax rates for working and nonworking recipients to provide additional incentives to those who could work. Recipients who were not able to work would receive a higher guarantee and a high

\footnotetext{
${ }^{3}$ Milton Friedman had insisted that any negative income tax program have a maximum marginal tax rate of 50 percent (Burke and Burke, 1974). The Family Assistance Plan failed this test because it did not account for the benefit reductions in food stamps, and payroll and state income taxes, which raised the rate over the 50 percent threshold.
} 
benefit reduction rate, whereas those who were expected to work would receive a lower benefit but would be able to keep more of their earnings.

The Family Support Act of 1988 reduced marginal tax rates by increasing the disregard for work expenses to $\$ 90$ from $\$ 75$. The maximum deductible child care expense also rose to $\$ 175$ (\$200 for children under two years) from $\$ 160$. The Family Support Act lowered the implicit tax on earnings by mandating that child care expenses be deducted after the $\$ 30$ and one-third deduction, which increased the value of the $\$ 30$ and one-third.

"Making Work Pay" is a central theme of the Clinton welfare reform strategy. To help make work a more attractive option than welfare, the EITC was expanded as part of the 1993 budget legislation. By 1996, when the EITC expansion is fully phased in, the EITC will raise the after-tax wage by 40 (34) percent for taxpayers with two or more children (one child) and earnings in the subsidy range of the credit. ${ }^{4}$ For taxpayers with children and earnings above $\$ 11,000$, however, the EITC will increase marginal tax rates by 16 percentage points for taxpayers with one child (on earnings up to $\$ 23,760$ ) and 21 percentage points for taxpayers with two or more children (on earnings up to $\$ 27,000$ ). Thus, for taxpayers in the phaseout range of the credit, the EITC adds significantly to the marginal tax rates these taxpayers will face. ${ }^{5}$

Despite periodic federal efforts to lower marginal tax rates on transfer program recipients, there are fundamental tradeoffs in the ability of transfer programs to maintain desirable incentives, be generous, and have well-targeted benefits. The 1993 expansion of the EITC, for example, significantly increases payments to low-income workers but, to maintain desirable incentives, EITC payments will be made to taxpayers with incomes up to $\$ 27,000$. Thus, the EITC is not tightly targeted on the poor.

\footnotetext{
${ }^{4}$ The subsidy range of the credit is from $\$ 1$ to $\$ 6,000$ for taxpayers with one child and $\$ 1$ to $\$ 8,425$ for taxpayers with two or more children (dollar amounts are in 1994 dollars).

${ }^{5}$ In 1990 the EITC subsidy was 14 percent on earned incomes from $\$ 1$ to $\$ 6,810$, and was phased out at a 10 percent rate on incomes from $\$ 10,730$ to $\$ 20,264$. The credit did not vary by family size.
} 
AFDC, by imposing a high tax rate on earnings in excess of disregards, is well targeted, but imposes undesirable incentives on recipients who want to work.

States have addressed the inherent tradeoffs in transfer program goals in different ways. Mississippi, for example, has well-targeted benefits and maintains desirable work incentives by keeping AFDC benefits low. Because of generous benefit levels, AFDC recipients in New York face higher marginal tax rates on earnings if they work than does an otherwise equivalent family in Mississippi. Recent AFDC waivers in California, Michigan, Utah, Vermont, and Wisconsin manipulate implicit marginal tax rates as a way to promote work (Wiseman, 1993). California's waiver eliminates the time limit on the $\$ 30$ and one-third earned income disregard. All other states with waivers change the lump sum and percentage of income that is disregarded, in addition to removing the time limit on the earnings disregard.

\section{THE MICROSIMULATION MODEL}

To calculate marginal tax rates we develop a model that accurately represents program rules and their complex interactions, using monthly data from the 1990 SIPP on family composition, income, program participation, and labor force status for the period January to December 1990. Monthly data are useful because income, labor force participation, assets, and family composition vary across months. This monthly variation affects program eligibility, participation, and implicit tax rates. Using SIPP allows us to make fewer imputations than would be required if we used annual data, such as the Current Population Survey (CPS). In addition, SIPP provides a high level of detail on sources of income, particularly for low-income households. ${ }^{6}$

${ }^{6}$ Relative to the CPS, SIPP's sample includes roughly one-third as many households. SIPP does not separately identify all 50 states because 9 smaller states are combined into three groups for confidentiality reasons. 
All modules have a common structure: each defines the unit of analysis for tax and transfer programs, performs income and asset tests or determines adjusted gross income and taxable income, and determines benefits or taxes. All parameters for the 1990 tax and transfer system are read in as separate files, so many program details can be changed without altering the internal operation of the model. In the "alpha" version of the model, household composition is fixed in the transfer program modules. Federal and state income taxes are calculated on the basis of the demographic structure of household members as of December 1990, as the tax code requires. Households with members in the sample for less than the full year are dropped owing to the complexity of imputing data for missing months.

The microsimulation model processes the SIPP data household by household. The model uses one module's output when simulating other programs, which imposes a natural ordering of the modules. For example, SSI recipients are excluded from AFDC filing units, so the SSI module precedes the AFDC module. Also, the food stamp program counts SSI and AFDC as income, but not the reverse; therefore, the two cash transfer programs are simulated before food stamps. The model simulates SSI, AFDC, food stamps, payroll taxes, federal income taxes, and state income taxes in the given order.

\section{$\underline{\text { SSI }}$}

The SSI unit is an individual or couple that is 65 years or older or disabled. ${ }^{7}$ The SSI program defines disability as any condition that makes a person "unable to engage in any substantially gainful activity." We identify the disabled as those who report themselves as unable to work because of a disability and who receive government benefits because of their disability. Categorically eligible units must have countable assets below federal limits, which are $\$ 2,000$ for an individual and $\$ 3,000$

\footnotetext{
${ }^{7}$ Blind individuals or couples are also eligible for SSI, but the core SIPP data does not identify whether a household member is blind.
} 
for a couple. ${ }^{8}$ Almost all of these assets are reported in SIPP, with the important exception of cash on hand. Receipt of income from assets is reported monthly, and the levels of income-producing assets are estimated by capitalizing monthly interest and dividend receipts by an average rate of return.

SSI units that meet the asset eligibility test receive benefits only if their countable income falls below the payment standard. Countable income is calculated by first determining total income. ${ }^{9}$ The model captures the fact that income of an ineligible spouse or parents of an eligible child can be deemed to be available for the SSI recipients and hence may reduce their benefits. To determine countable income, SSI excludes $\$ 20$ of monthly income from any source and $\$ 65$ in addition to half of the remainder of earned income. Thus, after disregards, the implicit tax rate of SSI is 50 percent, while the implicit tax rate on unearned income is 100 percent after minimal disregards.

The federal government sets a national SSI benefit standard for individuals and couples. ${ }^{10}$ Some states choose to supplement this benefit standard. We calculate benefits as the difference between the combined federal and state benefit standards and countable income (as defined by the federal government). Benefits differ depending on whether one is eligible as an individual or is eligible as an individual living with an ineligible spouse. If an SSI-eligible person lives with an ineligible spouse, we calculate their benefits as the minimum of benefits calculated for the person as

${ }^{8}$ Countable assets include cash, savings and checking accounts, savings certificates, stocks and bonds, IRAs and Keogh plans, nonrecurring lump sum payments, the fair market value of autos in excess of $\$ 4,500$, and the equity value of property not producing income (excluding homes).

${ }^{9}$ Total income includes wage and salary income, incidental or casual earnings, National Guard income, employer or temporary sickness income, property income, dividend and interest income, and other miscellaneous income. The value of federal in-kind transfers such as food stamps and in-kind support by private nonprofit organizations is (appropriately) excluded from total income.

${ }^{10}$ If an SSI recipient lives in the household of another and receives support from that person, the federal benefit standard is reduced by one-third. Fewer than 6 percent of SSI recipients had their benefits reduced for this reason. We do not model this reduction. 
an individual and benefits calculated for the person living with an ineligible spouse, as described in the SSI regulations.

Because we are interested in simulating the distribution of cumulative marginal tax rates, it is important that we calculate accurately the number of households receiving transfers. There is a large amount of evidence that program participation rates are considerably below 100 percent (see Blank and Ruggles, 1993, for a recent example). For each program, therefore, the model needs a participation algorithm that accurately identifies transfer recipients. We have taken a simpler approach in the alpha version of the model. We restrict eligibility by ignoring certain disregards (such as child care and work expenses) and by maintaining tight standards for categorical eligibility (such as using a restrictive definition of disability). Given our overly restrictive definitions of eligibility, we then assume 100 percent of eligibles participate in SSI and AFDC. Participation in the food stamp program is determined by including those who report receipt of food stamps in the SIPP, those who also receive either SSI or AFDC, and those who are randomly selected to bring food stamp participation in line with the administrative figures. ${ }^{11}$

Table 1 summarizes the model's ability to match administrative data on program participation and expenditures. The top panel compares our simulation model results for SSI with administrative data reported in the Green Book (U.S. Congress, 1993). We overstate the number of monthly recipients. The $\$ 218$ average monthly benefit for those who receive SSI is somewhat lower than the \$261 total given in the Green Book, but our estimated figure per household is close to the administrative sources.

$\underline{\mathrm{AFDC}}$

\footnotetext{
${ }^{11}$ Incorporating models of program participation and identifying eligible households is a high priority as we further develop the model.
} 
The AFDC module is complicated by diverse state eligibility rules and benefit levels. The basic unit is formed by putting all children under 18 (or in some states, 18-year-old students) if they are living with a relative into an AFDC unit with their parents, stepparents (when allowed), or related guardian. If the state provides benefits to pregnant women, we form units of pregnant women and their spouses (if they are present) who have not already been included in a unit. Children (including unborn children in the case of pregnant women) are categorically eligible for AFDC if they are deprived of parental support because one or both of the parents are absent, incapacitated or, in 26 states, unemployed. The AFDC module uses disability determination from the SSI module to identify two-parent households that are eligible because one parent is incapacitated. Consistent with federal regulation, SSI recipients are excluded from the final AFDC unit using simulated participation from the SSI module. We also identify and exclude strikers from the final AFDC unit.

AFDC eligibility depends on households having countable assets less than the $\$ 1,000$ federal limit. $^{12}$ In addition, each unit must pass two income tests. First, total earned and unearned income cannot exceed 185 percent of the state's need standard based on family size. Second, countable income cannot exceed the state's payment standard. AFDC countable income is calculated by

\footnotetext{
${ }^{12}$ Countable assets income all real and personal property except the value of the home, funeral arrangements, personal effects and up to $\$ 1,500$ for a vehicle.
} 
TABLE 1

Base-Case Output of the Model Compared with Administrative Data on Three Income Transfer Programs, 1990

Administrative Data

(Green Book)

Supplemental Security Income ${ }^{\mathrm{a}}$

Total 1990 benefits (millions)

Number of recipients (monthly)

Average monthly benefits

Aid to Families with Dependent Children ${ }^{c}$

Total 1990 benefits (millions)

Number of families (monthly)

Number of recipients (monthly)

Average monthly benefits

Food Stamps ${ }^{\mathrm{d}}$

Total 1990 benefits (millions)

Number of households (monthly)

Number of recipients (monthly)

Average monthly benefits

$$
\begin{array}{r}
\$ 16,599 \\
4,817,127 \\
\$ 261
\end{array}
$$

$\$ 18,539$

$3,974,000$

$11,460,000$

$\$ 389$

$\$ 15,090$

$8,200,000^{\mathrm{e}}$

$21,500,000$

$\$ 153^{\mathrm{f}}$
Base-Case

Model Output

${ }^{a}$ Administrative data from U.S. Congress (1993), Table 1, p. 815.

${ }^{b}$ This is average monthly benefit per recipient. The average monthly benefit per household is $\$ 251$. ${ }^{c}$ U.S. Congress (1993), Table 1, p. 616.

${ }^{\mathrm{d} U . S . ~ C o n g r e s s ~(1993), ~ T a b l e ~ 1, ~ p . ~ 1609, ~ a n d ~ T a b l e ~ 12, ~ p . ~} 1632$.

${ }^{\mathrm{e}}$ Total number of recipients (21.5 million) divided by average household size (2.6).

${ }^{\mathrm{f}}$ Average monthly payment per person (\$59) times average household size (2.6). 
subtracting from earnings $\$ 90$ per month for work expenses, as much as $\$ 175$ per child per month for child care expenses, and, for the first four months of work, $\$ 30$ plus an additional one-third of remaining earnings. This implies that the marginal tax rate on income that exceeds work and child care expenses (and the $\$ 30$ disregard) is $662 / 3$ percent for the first four months of work. After four consecutive months the implicit tax rate increases to 100 percent after work and child care expenses (and $\$ 30$ for eight additional months) are considered. ${ }^{13}$ All earned income of students is also disregarded.

States use a variety of methods to calculate payment standards and benefits. We capture these variations in the model. In 1990, 16 states paid benefits equal to the difference between the need standard and countable income. Four states paid benefits equal to a "ratable reduction" of this difference. Nineteen states reduced the need standard by a "ratable reduction" and paid the difference between the reduced need standard and countable income. Finally, twelve states applied one of these formulas but place a maximum on the benefit level.

The middle panel of Table 1 compares our estimates of AFDC participation and benefits with administrative data reported in the Green Book (U.S. Congress, 1993). The model slightly understates the number of families and individuals receiving AFDC. The model's average family size, however, appears to be very close to the implied family size from the administrative source. Also, the average monthly benefits are very close to the actual average monthly benefits.

\footnotetext{
${ }^{13} \mathrm{We}$ do not estimate child care deductions for households in this version of the model. We also do not account for the additional one-third earned income deduction. This is especially important for calculating marginal tax rates because we are assuming that the implicit tax on earnings is 100 percent beyond the disregard. An average of 50.6 percent of AFDC households with earned income (13.2 percent of all AFDC households have earned income) have the $\$ 30$ plus one-third disregard (U.S. Congress, 1993). We can address both shortcomings in subsequent versions of the model using data from the SIPP topical modules.
} 


\section{$\underline{\text { Food Stamps }}$}

The food stamp module assumes that relatives living together are included in the same filing unit. If parents with minor children are present in a larger household, they are split off to form a separate filing unit. Disabled persons are identified by the SSI module, and any elderly or disabled persons and their spouses are placed in their own filing unit. Unrelated individuals in a household are assumed to purchase and prepare food separately and to file for food stamps as individuals. Students are excluded from the final food stamp unit, unless they meet food stamp earnings or hours worked requirements.

Households composed entirely of AFDC or SSI recipients are automatically eligible for food stamps and therefore do not need to pass either the asset or gross income tests. All other households must have "countable" assets (see footnote 8) and monthly income below federal limits. The countable asset limits are higher for households with an elderly member.

For asset-eligible households, the food stamp module simulates the income eligibility tests by first summing a household's monthly cash income from all sources. Monthly gross income cannot exceed 130 percent of the federal poverty guidelines. Gross income includes all of the household's cash income (less some nonrecurring lump-sum payments), plus SSI or AFDC payments calculated in earlier modules. The model captures the fact that households composed entirely of elderly and disabled members do not need to pass the gross income test.

For households eligible to this point, countable income is calculated by applying a standard deduction of $\$ 127$ and excluding 20 percent of earned income. ${ }^{14}$ Except for those who are

\footnotetext{
${ }^{14}$ Additional deductions are allowed for dependent care expenses up to $\$ 160$ and shelter expenses that exceed 50 percent of countable income after the other deductions. We do not incorporate the dependent care and shelter expense deductions in the current model. In subsequent versions we will use child care expenses calculated in the AFDC module. Shelter expenses will be imputed and compared to income after deductions to determine if the food stamp household has shelter expenses exceeding 50 percent of counted income and is therefore eligible for an additional deduction. Finally, deductions for medical expenses will be imputed for households that include an elderly or disabled
} 
automatically eligible, households cannot have counted income that exceeds the federal poverty guidelines. Participating households are expected to contribute 30 percent of their counted income toward food purchases, thus, the implicit marginal tax rate on countable income (which includes AFDC or SSI benefits) is 30 percent. A household's benefit is determined by the appropriate maximum allotment based on the food unit's size less 30 percent of counted income.

The layering of programs is complicated and may lead to even higher benefit reduction than one would calculate examining programs in isolation. ${ }^{15}$ For example, a person receiving benefits from both AFDC and food stamps and who has earned income exceeding the AFDC disregards would face a $662 / 3$ percent marginal tax rate on AFDC. From the perspective of the food stamp program, earned income increases by 80 cents for every dollar of earnings (due to the 20 percent disregard for earnings), but unearned income would have fallen by $662 / 3$ cents for every dollar of earnings (the reduction in AFDC benefits). The net of these amounts, 131/3 cents, is the increase in food stamp "countable income" for every dollar of earnings, and is taxed at a 30 percent rate, which implies an additional 4 percent marginal tax rate. Thus, the statutory marginal tax rate on earnings (beyond the disregards) in the first four months of employment for a person receiving AFDC and food stamps is $702 / 3$ percent; after four months it is 94 percent. $^{16}$

The bottom panel of Table 1 compares our estimates of food stamp participation and benefits with administrative data reported in the Green Book (U.S. Congress, 1993). The model does a fairly

member.

${ }^{15}$ See Wilson and Cline (1994) for a detailed description of Minnesota's cumulative income tax and transfer program tax rates.

${ }^{16}$ After four months of earnings, the AFDC implicit tax rate on earnings increases to 100 percent, so AFDC benefits fall dollar for dollar. This 100 percent marginal tax is slightly offset by the food stamp program because, although food stamp earned income still increases by 80 cents for every dollar of earnings, unearned income would have fallen by one dollar. Food stamp countable income therefore falls by 20 cents and food stamp benefits would increase by 6 cents for every dollar of earnings. 
good job in matching food stamp administrative data. In particular, the model only slightly overstates the number of families and individuals receiving food stamps in a given month. The average monthly benefits, however, are considerably lower than the implied monthly benefits from the administrative source.

\section{$\underline{\text { Federal Income Tax }}$}

The first part of the federal tax module determines the appropriate tax filing status. All subfamilies, primary individuals, and secondary individuals are treated as potentially separate (from the primary family) tax filing units. After filing units are determined, the model generally follows the 1040 tax schedule. Exemptions are claimed for children and other adult dependents. We assume that adults living in the household who have gross income less than $\$ 2,050$ are dependents. Total income includes wage and salary income, taxable interest and dividend income, alimony, business income, taxable pensions and annuities, rents, royalties, income from partnerships, estates and trusts, unemployment compensation, taxable social security, and other miscellaneous income. Adjusted Gross Income (AGI) in the model excludes adjustments to AGI. Taxable income is calculated by subtracting from AGI the standard deduction (for all taxpayers) and exemptions. Taxes before credits are calculated using the appropriate tax schedules for each filing unit. Tax liabilities are adjusted by nonrefundable credits for the elderly or disabled and the refundable EITC. The EITC calculations are described in detail in Scholz (1994).

Table 2 compares our simulated distribution of average tax rates with tax return data from the Internal Revenue Service (1993). Average rates on low-income households in our model are somewhat lower than those shown in the income tax data. Recall, however, that the units of analyses differ across the two data sources. The IRS data include returns filed, for example, by children working part-time jobs. These returns will appear as low-income filers, but will not be eligible for the EITC. Our low-income filers are more likely to be heads of households than those in the IRS 
TABLE 2

The Model's Estimated Average Federal Income Tax Rates Compared with Income Tax Data, 1990

\begin{tabular}{lcc}
\hline & \multicolumn{2}{c}{ Average Tax Rate } \\
\cline { 2 - 3 } AGI or Market Income & Statistics of Income ${ }^{\mathrm{a}}$ & Model \\
\hline$\$ 1$ to $\$ 5,000$ & $-0.56 \%$ & $-3.63 \%$ \\
$\$ 5,000$ to $\$ 10,000$ & 0.37 & -0.77 \\
$\$ 10,000$ to $\$ 15,000$ & 3.74 & 1.36 \\
$\$ 15,000$ to $\$ 20,000$ & 7.05 & 4.44 \\
$\$ 20,000$ to $\$ 30,000$ & 9.06 & 7.63 \\
$\$ 30,000$ to $\$ 50,000$ & 10.98 & 11.45 \\
$\$ 50,000$ to $\$ 100,000$ & 14.04 & 16.52 \\
over $\$ 100,000$ & 21.61 & 22.32 \\
\hline
\end{tabular}

${ }^{a}$ Internal Revenue Service (1993), Table 1.1, p. 16. and Table 3.3, pp. 52-53. 
data, and hence are more likely to receive the EITC. Thus, we consistently understate the tax rates of low-income households. In contrast, we overstate the average rates of high-income households as we do not yet allow taxpayers in the model to itemize deductions.

\section{$\underline{\text { State Income Taxes }}$}

State tax liabilities are based on the tax laws of the household's state of residence in December 1990. We assume that the household's filing status for state income taxes is the same as for federal taxes. ${ }^{17}$ States have different definitions of taxable income, and this variation is reflected in the model. Twenty-four states use federal AGI, nine use federal taxable income, nine calculate taxable income separately from the federal return, two base their income taxes on the federal tax liability, and the other seven have no income tax.

After the appropriate income measure is calculated, certain income sources are excluded. For example, most states exempt all social security benefits from taxation. Standard deductions and exemptions are then calculated and deducted. Some states use a percentage of state AGI as the standard deduction and many use the federal standard deduction. Tax liability is calculated using brackets and rates for each state and filing status.

Besides determining tax liability, tax credits are calculated. The state tax module currently supports credits for low-income filers (nine states), the elderly and disabled (eight states), dependents (one state), and exemptions (six states). Credits vary among states with regard to eligibility, generosity, and whether the credits are refundable. New Mexico, in particular, has a low-income credit that uses "modified AGI." Modified AGI includes AFDC, SSI, and food stamp benefits that we calculate in earlier modules. As with the other modules, the addition of data from the SIPP topical modules will allow us to model child care credits as well.

\footnotetext{
${ }^{17}$ This assumption does not reflect the fact that eleven states allow couples to file combined separate returns to mitigate potential marriage penalties.
} 
Table 3 presents simulated average state income tax rates compared to average tax rates drawn from the Statistical Abstract of the United States (U.S. Bureau of the Census, 1992). Simulated rates range from zero percent in states without state income taxes to an average rate of 5.5 percent for the District of Columbia. The District is also the high tax "state" in the administrative data. There are clearly discrepancies between the actual and simulated tax rates across states, but we view the model's ability to generate realistic state tax rates to be strikingly good, particularly because the SIPP is not designed to produce state-level estimates. It is also clear from the table that there is considerable variation across the states in burdens imposed by the state income tax.

\section{$\underline{\text { Payroll Taxes }}$}

We assume the payroll tax is borne entirely by the employee and therefore compute it as 15.3 percent (the combined 7.65 percent employer and employee share) of wage and salary income. Incomes above $\$ 51,300$ are not subject to payroll tax. Payroll taxes on the self-employed are computed according to the federal income tax schedule for self-employed taxpayers.

\section{RESULTS}

We use the model to characterize the monthly budget constraints faced by low-income households. We simulate the marginal tax rates these households face by computing the change in after-tax and after-transfer income that results from adding $\$ 10$ of earned income to the monthly income of each household member age 15 or older. The most interesting policy question, however, may not be what is the marginal tax rate on incremental earnings, but rather, what is the change in consumable income that results when household members significantly increase their hours of work? 
TABLE 3

\section{Average Simulated State Income Tax in 1990 Compared to} the Actual Average State Income Taxes

\begin{tabular}{|c|c|c|}
\hline $\begin{array}{l}\text { as a Percentage of } \\
\text { State }\end{array}$ & $\begin{array}{l}\text { State Income Taxes } \\
\text { Taxes as a Percentage of } \\
\text { State Personal Income }\end{array}$ & $\begin{array}{l}\text { Simulated State Income } \\
\text { Market Income, } 1990\end{array}$ \\
\hline Alabama & $1.9 \%$ & $2.1 \%$ \\
\hline Alaska $^{\mathrm{b}}$ & 0.0 & 0.0 \\
\hline Arizona & 1.8 & 2.0 \\
\hline Arkansas & 2.2 & 2.3 \\
\hline California & 2.7 & 1.5 \\
\hline Colorado & 2.2 & 3.1 \\
\hline Connecticut & 0.7 & 0.0 \\
\hline Delaware & 3.4 & 3.1 \\
\hline District of Columbia & 4.5 & 5.5 \\
\hline Florida & 0.0 & 0.0 \\
\hline Georgia & 2.6 & 2.0 \\
\hline Hawaii & 3.1 & 2.2 \\
\hline Idaho $^{\mathrm{b}}$ & 2.6 & 1.8 \\
\hline Illinois & 1.8 & 2.2 \\
\hline Indiana & 2.2 & 2.5 \\
\hline Iowa $^{\mathrm{b}}$ & 2.6 & 3.2 \\
\hline Kansas & 1.9 & 1.9 \\
\hline Kentucky & 2.2 & 2.9 \\
\hline Louisiana & 1.2 & 1.4 \\
\hline Maine $^{\mathrm{b}}$ & 2.7 & 3.4 \\
\hline Maryland & 2.7 & 3.3 \\
\hline Massachusetts & 3.6 & 3.8 \\
\hline Michigan & 2.3 & 3.1 \\
\hline Minnesota & 3.5 & 2.6 \\
\hline Mississippi & 1.3 & 1.1 \\
\hline Missouri & 2.0 & 2.2 \\
\hline Montana $^{\mathrm{b}}$ & 2.3 & 3.2 \\
\hline Nebraska & 1.8 & 2.0 \\
\hline Nevada & 0.0 & 0.0 \\
\hline New Hampshire & 0.2 & 0.0 \\
\hline New Jersey & 1.5 & 1.7 \\
\hline New Mexico & 1.7 & 1.3 \\
\hline New York & 3.8 & 2.8 \\
\hline North Carolina & 3.1 & 1.7 \\
\hline North Dakota ${ }^{\mathrm{b}}$ & 1.1 & 1.7 \\
\hline
\end{tabular}

(table continues) 
TABLE 3, continued

\begin{tabular}{|c|c|c|}
\hline $\begin{array}{l}\text { as a Percentage of } \\
\text { State }\end{array}$ & $\begin{array}{l}\text { State Income Taxes } \\
\text { Taxes as a Percentage of } \\
\text { State Personal Income }{ }^{\mathrm{a}}\end{array}$ & $\begin{array}{l}\text { Simulated State Income } \\
\text { Market Income, } 1990\end{array}$ \\
\hline Ohio & 2.2 & 2.1 \\
\hline Oklahoma & 2.1 & 1.7 \\
\hline Oregon & 3.7 & 3.2 \\
\hline Pennsylvania & 1.5 & 1.6 \\
\hline Rhode Island & 2.3 & 2.8 \\
\hline South Carolina & 2.6 & 1.4 \\
\hline South Dakota ${ }^{\mathrm{b}}$ & 0.0 & 0.0 \\
\hline Tennessee & 0.1 & 0.0 \\
\hline Texas & 0.0 & 0.0 \\
\hline Utah & 2.7 & 2.3 \\
\hline Vermont $\mathrm{t}^{\mathrm{b}}$ & 2.5 & 3.3 \\
\hline Virginia & 2.5 & 3.2 \\
\hline Washington & 0.0 & 0.0 \\
\hline West Virginia & 2.1 & 2.0 \\
\hline Wisconsin & 3.0 & 4.0 \\
\hline Wyoming $^{\text {b }}$ & 0.0 & 0.0 \\
\hline
\end{tabular}

${ }^{a}$ U.S. Bureau of the Census (1992), Table 463, p. 290, and Table 687, p. 438.

${ }^{\mathrm{b}} \mathrm{SIPP}$ aggregates nine states into three groups for confidentiality reasons. We randomly divided households within these groups to a specific state in the group. Alaska, Idaho, Montana, and Wyoming are combined. Iowa, North Dakota, and South Dakota are combined. Maine and Vermont are combined. 
Thus we also calculate the change in after-tax and after-transfer income that results when each household member age 15 or older takes a half-time minimum-wage job. ${ }^{18}$

Table 4 shows the variation of marginal tax rates within income groups that arises from adding $\$ 10$ per month to the earned income of each household member age 15 or older. We divide household income by the poverty line, which increases with family size, as a way of adjusting household incomes for the additional costs of family members. For each income-to-poverty class (the rows of the table), we present the marginal tax rates faced by households in the 10th, 50th, and 90th percentile of the cumulative marginal tax rate distribution. The last column shows the mean marginal tax rate for the income-to-poverty class.

There is a great deal of variation in marginal tax rates within income groups, particularly for low-income households. The 10th percentile marginal tax rate, for example, on households with incomes 75 to 100 percent of the poverty line is 15.3 percent, while the median rate is 24.2 percent and the 90th percentile rate is 41.7 percent. Variation within an income group arises from differences in benefits available to childless households (food stamps), single-parent households (AFDC, food stamps, and the EITC), and elderly households (food stamps and SSI). State income taxes and AFDC also vary greatly among states and so contribute to within-group variation. There is less variation in tax rates on households with incomes well above the poverty line. These households face relatively uniform treatment from payroll and income taxes, though the model understates variation for high-income households by forcing all taxpayers to use the standard deduction.

In general, the pattern of median marginal tax rates is U-shaped, very poor households and very wealthy households having higher marginal tax rates than middle-income households. It is

\footnotetext{
${ }^{18}$ Throughout the analysis we ignore changes in expenses that may occur when a household member increases income by increasing labor hours. For example, consumable income may fall with an increase in labor income if increasing labor force participation results in increased child care expenses.
} 
TABLE 4

\section{Weighted Cumulative Marginal Tax Rates (MTR) on Earnings, by Income Groups (Expressed as Market-Income-to-Poverty Ratios), 1990}

\begin{tabular}{|c|c|c|c|c|}
\hline $\begin{array}{l}\text { Market Income/ } \\
\text { Poverty Line }{ }^{b}\end{array}$ & $\begin{array}{l}\text { 10th Percentile } \\
\text { MTR }^{\mathrm{c}}\end{array}$ & Median MTR $^{\mathrm{c}}$ & $\begin{array}{l}\text { 90th Percentile } \\
\text { MTR }^{\mathrm{c}}\end{array}$ & Mean MTR $^{\mathrm{d}}$ \\
\hline $0-.5$ & $12.5 \%$ & $25.3 \%$ & $39.3 \%$ & $28.0 \%$ \\
\hline $.5-.75$ & 15.3 & 27.6 & 39.3 & 29.0 \\
\hline $.75-1.0$ & 15.3 & 22.4 & 41.7 & 25.5 \\
\hline $1.0-1.25$ & 15.3 & 23.3 & 44.3 & 26.9 \\
\hline $1.25-1.5$ & 15.3 & 21.5 & 43.3 & 26.2 \\
\hline $1.5-2$ & 15.3 & 30.3 & 41.7 & 29.2 \\
\hline $2-3$ & 22.3 & 33.3 & 36.8 & 31.7 \\
\hline $3-5$ & 30.3 & 36.3 & 49.3 & 38.5 \\
\hline $5+$ & 36.8 & 46.3 & 51.2 & 45.3 \\
\hline
\end{tabular}

${ }^{a}$ The sample size is 16,200 . Entries are weighted using the SIPP sample weights. Marginal tax rates are calculated by adding $\$ 10$ to the wage income of every person in the household age 15 or older.

${ }^{b}$ Market income is the sum of labor and capital income and is measured before taxes and transfers. The poverty line in 1990 was $\$ 6,800$ for a 1 -person family $(\$ 6,268$ if the person was over 65$), \$ 9,521$ for a 2-person family (\$8,558 if the head was older than 65), $\$ 10,419$ for a 3-person family, $\$ 13,359$ for a 4-person family, $\$ 15,792$ for a 5-person family, $\$ 17,839$ for a 6-person family, $\$ 20,241$ for a 7 person family. For families with more than 7 people we add $\$ 2,100$ for every additional person.

'The 10th, median, and 90th percentile marginal tax rates are the combined, implicit and explicit marginal tax rates that apply to the 10th, 50th, and 90th percentiles of cumulative marginal tax rate distributions.

${ }^{\mathrm{d}}$ The mean marginal tax rate is the average marginal tax rate for a household in the given income-topoverty class. 
somewhat surprising that the highest rate on low-income households shown in the table, 44.3 percent, is not even higher, given the range of explicit and implicit taxes faced by low-income households. In practice, disregards and the EITC effectively reduce the burden of high statutory benefit reduction rates associated with income transfer programs.

Many policies directed at low-income households try to make work more attractive than welfare. When considering these "make work pay" policies, the change in after-tax and after-transfer income that results from taking a job is a more useful measure of the incentives a low-income household faces than the tax rates on incremental earnings shown in Table 4. Table 5 has an identical format to Table 4, but we calculate the change in after-tax and after-transfer income that results when everyone in the household age 15 and older takes a half-time, minimum-wage job (modeled as increasing household income by $\$ 340$ per month, per person age 15 and older).

Table 5 confirms our intuition that when large changes in earned income are considered, it is the poorest households who face the highest marginal tax rates. The U-shaped pattern is even more striking for the larger increment in income. For households with incomes below the poverty line, earnings from the half-time minimum-wage job exceed the disregards and therefore cause a sharp reduction in benefits. The 90th percentile marginal tax rates on households with incomes 0 to 50 percent of the poverty line are higher than the 90th percentile rates in any other income group. These households would receive only a 29 cent increase (i.e., face a tax rate of 71 percent) in their after-tax and after-transfer income for every dollar earned from employment. The median marginal tax rates range from 29 to 47 percent for households with incomes below the poverty line. Households with incomes 100 to 150 percent of the poverty line lose all program benefits, but because benefits were small to start with for these households, the additional earnings are actually taxed at a lower rate than for lower-income households. Tax rates for higher-income households are largely the same as for the 
TABLE 5

\section{Weighted Cumulative Marginal Tax Rates (MTR) on Earnings from a Half-Time Minimum-Wage Job, by Income Groups (Expressed as Market-Income-to-Poverty Ratios), 1990}

\begin{tabular}{lcccc}
\hline $\begin{array}{l}\text { Market Income/ } \\
\text { Poverty Line }^{\mathrm{b}}\end{array}$ & $\begin{array}{c}\text { 10th Percentile } \\
\text { MTR }^{\mathrm{c}}\end{array}$ & Median MTR $^{\mathrm{c}}$ & $\begin{array}{c}\text { 90th Percentile } \\
\text { MTR }^{\mathrm{c}}\end{array}$ & Mean MTR $^{\mathrm{d}}$ \\
\hline $0-.5$ & $19.6 \%$ & $46.5 \%$ & $70.6 \%$ & $45.4 \%$ \\
$.5-.75$ & 20.4 & 37.8 & 55.7 & 38.4 \\
$.75-1.0$ & 15.3 & 28.8 & 53.2 & 31.1 \\
$1.0-1.25$ & 15.3 & 30.3 & 46.0 & 29.8 \\
$1.25-1.5$ & 15.3 & 30.3 & 43.5 & 28.9 \\
$1.5-2$ & 18.1 & 32.4 & 39.0 & 31.2 \\
$2-3$ & 28.0 & 33.7 & 38.9 & 43.6 \\
$3-5$ & 32.8 & 41.2 & 49.3 & 45.9 \\
$5+$ & 39.0 & 46.7 & 51.2 & \\
\hline
\end{tabular}

${ }^{a}$ The sample size is 16,200 . Entries are weighted using the SIPP sample weights. Marginal tax rates are calculated by adding $\$ 340$ to the wage income of every person in the household 15 or older.

${ }^{b}$ Market income is the sum of labor and capital income and is measured before taxes and transfers. The poverty line in 1990 was $\$ 6,800$ for a 1 -person family $(\$ 6,268$ if the person was over 65$), \$ 9,521$ for a 2-person family (\$8,558 if the head was older than 65$), \$ 10,419$ for a 3-person family, $\$ 13,359$ for a 4-person family, $\$ 15,792$ for a 5-person family, $\$ 17,839$ for a 6 -person family, $\$ 20,241$ for a 7 person family. For families with more than 7 people we add $\$ 2,100$ for every additional person.

${ }^{\mathrm{c}}$ The 10th, median, and 90th percentile marginal tax rates are the combined, implicit and explicit marginal tax rates that apply to the 10th, 50th, and 90th percentiles of cumulative marginal tax rate distributions.

${ }^{\mathrm{d}}$ The mean marginal tax rate is the average marginal tax rate for a household in the given income-topoverty class. 
$\$ 10$ income increment, owing to the general lack of progressivity in the marginal tax rate distribution for working households.

There are many other ways to examine the tax burdens on low-income households. In Table 6 we examine cross-state variation in tax burdens from state income taxes and AFDC-programs the states largely control—on households with incomes below the poverty line. States shown in the table are selected because they have the largest sample sizes (the state with the smallest sample, West Virginia, has 40 observations).

The level of marginal tax rates shown in the first column of Table 6, where we examine the rates from a small change in monthly earned income, is low. Most state income taxes have exemptions and deductions that significantly reduce (or eliminate) taxes on the poor. Also, many poor households (i.e., those without children) do not receive AFDC. Households that receive AFDC generally do not work, so the additional $\$ 10$ per month in income is sheltered by disregards.

Column 2 shows the change in after-tax and after-transfer income that results when family members take a half-time minimum-wage job. While the rates are again not exceptionally high (recall, many poor households do not receive AFDC), there is striking variation across states. The variation is in part a reflection of the generosity of states' AFDC programs. In states with high benefit levels, households forgo more benefits if they increase their earned income. According to the Green Book (U.S. Congress, 1990), the median maximum monthly AFDC benefit for a family of three was $\$ 364$ in 1990. States such as California, Illinois, Minnesota, New Jersey, and New York have maximum state benefit levels above the median and also have high average marginal tax rates. For example, the maximum AFDC benefit for a three-person household in New York is \$577 and our estimated marginal tax rate is 9.8 percent. States such as Florida, Louisiana, Mississippi, North Carolina and Texas have maximum state benefit levels below the median and also have low average marginal tax rates. The maximum AFDC benefit for a three-person household in Mississippi is $\$ 120$ 
TABLE 6

Marginal State Income Taxes and AFDC Implicit Tax Rates by Selected States for Households with Incomes below the Poverty Line, 1990

\begin{tabular}{|c|c|c|}
\hline State & $\begin{array}{l}\text { Average Marginal Tax Rate with } \\
\$ 10 \text { Monthly Income Increment }\end{array}$ & $\begin{array}{l}\text { Average Tax Rate on Half-Time } \\
\text { Minimum-Wage Job } \\
(\$ 340 \text { per month })^{c}\end{array}$ \\
\hline Alabama & $0.73 \%$ & $2.42 \%$ \\
\hline California & 6.03 & 17.85 \\
\hline Florida & 0.19 & 2.94 \\
\hline Georgia & 3.22 & 7.91 \\
\hline Illinois & 4.86 & 10.43 \\
\hline Louisiana & 2.76 & 2.28 \\
\hline Minnesota & 2.07 & 9.36 \\
\hline Mississippi & 0.17 & 2.30 \\
\hline New Jersey & 1.56 & 11.37 \\
\hline New York & 4.47 & 9.80 \\
\hline North Carolina & 2.39 & 3.61 \\
\hline Ohio & 2.35 & 12.74 \\
\hline Pennsylvania & 4.69 & 7.73 \\
\hline Texas & 1.99 & 4.63 \\
\hline West Virginia & 3.32 & 8.29 \\
\hline
\end{tabular}

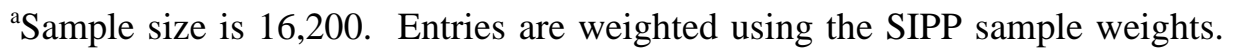

${ }^{b}$ This column shows the percentage reduction in AFDC benefits and state income tax increases caused by a $\$ 10$ increase in the monthly wage income of every household member 15 years old or older.

${ }^{\text {c}}$ This column shows the percentage reduction in AFDC benefits and state income tax increases caused by a $\$ 340$ increase in the monthly wage income of every household member 15 years old or older. 
and our estimated marginal tax rate is 2.3 percent. If taxes and benefits affect labor supply, particularly labor market participation, we should expect to see higher participation rates in, for example, Mississippi than in New York, controlling for observable characteristics.

In Table 7 we limit the sample to households receiving benefits from transfer programs. In the case of a $\$ 10$ marginal change in monthly income, we find that marginal tax rates on program participants range from 27.7 to 33.6 percent, which is similar to the rate of 27.3 percent faced by all households with incomes below the poverty line. The similarity again occurs because disregards keep tax rates low on incremental earnings. In addition, households participating in AFDC are eligible for the EITC as monthly earnings increase. Thus, in the incremental earnings case, poor households with children have lower tax rates, even when receiving program benefits, than poor households without children.

Column 2 of Table 7 shows the effect, conditional on program participation, of taking a halftime minimum-wage job. Marginal tax rates on program participants range from 40.0 percent for households participating in food stamps to 52.8 percent for households participating in AFDC and food stamps. These rates are somewhat higher than the rate of 37.9 faced by all household with income below the poverty line, because a half-time minimum-wage job puts many program recipients over the break-even income levels for program eligibility. Although the median marginal tax rates on program recipients are not exceptionally high, the 90th percentile tax rate for AFDC recipients is 81.8 percent. Tax rates of this magnitude undoubtedly hinder the effectiveness of policies like the EITC that attempt to improve labor market incentives.

\section{CONCLUSIONS}

In this paper we introduce a SIPP-based microsimulation model of the federal and state tax and transfer system. We use the model to calculate implicit and explicit tax rates faced by 
TABLE 7

Mean Cumulative Marginal Tax Rates Conditional on Program Participation, 1990 ${ }^{a}$

\begin{tabular}{lcc}
\hline & $\begin{array}{c}\text { Cumulative Marginal Tax } \\
\text { Rate, \$10 Monthly } \\
\text { Income Increment }\end{array}$ & $\begin{array}{c}\text { Cumulative Marginal Tax } \\
\text { Rate, \$340 Monthly } \\
\text { Income Increment }\end{array}$ \\
\hline Food Stamps & $33.6 \%$ & $42.7 \%$ \\
AFDC & 32.7 & 51.6 \\
SSI & 27.7 & 40.4 \\
SSI and Food Stamps & 30.8 & 40.0 \\
AFDC and Food Stamps & 32.7 & 52.8 \\
Overall for Households in Poverty & 27.3 & 37.9 \\
\hline
\end{tabular}

${ }^{\text {a } E n t r i e s ~ a r e ~ w e i g h t e d ~ u s i n g ~ t h e ~ S I P P ~ s a m p l e ~ w e i g h t s . ~ T h e ~ m a r g i n a l ~ t a x ~ r a t e s ~ a r e ~ c a l c u l a t e d ~ b y ~ a d d i n g ~}$ $\$ 10$ (\$340) to the wages of all people in the household age 15 or older. 
low-income households. Typical cumulative marginal tax rates on households with incomes below the poverty line are around 27.3 percent, but these rates mask a great deal of variation caused by differences in program eligibility, and state income tax and AFDC policies. For households with incomes equivalent to 50 to 75 percent of the poverty line, for example, the marginal tax rate on an increase of $\$ 10$ of earnings per month ranges from 15.3 percent at the 10 th percentile to 39.3 percent at the 90th percentile of the marginal tax rate distribution. When we simulate the effects of household members taking a half-time minimum-wage job, marginal tax rates on this income group range from 20.4 percent at the 10 th percentile to 55.7 percent at the 90 th percentile.

We find considerable variation across states in their tax treatment of households with incomes below the poverty line when we simulate the tax burdens resulting from taking a half-time minimum-wage job. This variation is strongly correlated with the level of AFDC benefits in a state. We also find, again in the case of a simulated minimum-wage job, that participants in AFDC and food stamps face median marginal tax rates significantly above the median marginal tax rates for all impoverished households. A consistent result in all of our experiments, however, is that typical tax rates on the poor are not particularly high—-they rarely exceed 60 percent—when we simulate the change in after-tax and after-transfer income that results from an incremental change in monthly labor market earnings. Disregards successfully protect the typical transfer program recipient from unusually high marginal tax rates, at least in the incremental earnings experiments. This result is consistent with earlier studies showing that effective tax rates on AFDC recipients were considerably below statutory rates. The cumulative rates discussed in this paper tend to be somewhat higher than the effective rates on AFDC recipients described in the earlier literature.

On the basis of the analyses described in the paper, we are left with a fairly upbeat message. For most low-income households, tax rates are not so high as to dismiss the possible effectiveness of policies, like the EITC, that try to make work more attractive than welfare. Program recipients in the 
highest percentiles of the cumulative tax rate distribution face prohibitively high marginal rates on earnings, but the typical poor household and program recipient does not. Further examination of the effectiveness of policies that manipulate labor market incentives, however, requires knowledge of labor market responses to variations in tax rates. The detailed simulation of household budget constraints described in this paper allows us to exploit the cross-state variation in tax treatment of households to examine these labor market responses. This, along with the model improvements described in this paper, is the next topic on our research agenda. 


\section{References}

Blank, Rebecca and Patricia Ruggles. 1993. "When Do Women Use AFDC and Food Stamps? The Dynamics of Eligibility Vs. Participation." Cambridge, Mass.: National Bureau of Economic Research, Working Paper no. 4429, August.

Burke, Vincent J. and Vee Burke. 1974. Nixon's Good Deed: Welfare Reform. New York: Columbia University Press.

Chernick, Howard and Andrew Reschovsky. 1990. "Taxation of the Poor." Journal of Human Resources 25(4) (Fall): 712-725.

Edin, Kathryn and Christopher Jencks. 1992. "Reforming Welfare." In Rethinking Social Policy: Race, Poverty, and the Underclass. Cambridge, Mass.: Harvard University Press.

Fraker, Thomas, Robert Moffitt, and Douglas Wolf. 1985 "Effective Tax Rates and Guarantees in the AFDC Program, 1967-1982." Journal of Human Resources 20(2) (Spring): 251-263.

Fraker, Thomas and Robert Moffitt. 1988. "The Effect of Food Stamps on Labor Supply: A Bivariate Selection Model." Journal of Public Economics 35(1) (February): 25-56.

Heffernan, W. Joseph. 1973. "Variations in Negative Tax Rates in Current Public Assistance Programs: An Example of Administrative Discretion." Journal of Human Resources 8 (Supplement): 56-68.

Hoynes, Hilary Williamson. 1993. "Welfare Transfers in Two-Parent Families: Labor Supply and Welfare Participation under AFDC-UP." Cambridge, Mass.: National Bureau of Economic Research, Working Paper no. 4407, July.

Hutchens, Robert M. 1978. "Changes in AFDC Tax Rates, 1967-1971." Journal of Human Resources 13(1) (Winter): 60-74. 
Internal Revenue Service. 1993. Statistics of Income-1990: Individual Income Tax Returns.

Washington, D.C.: U.S. Government Printing Office.

Keane, Michael and Robert Moffitt. 1991. "A Structural Model of Multiple Welfare Program Participation and Labor Supply." Institute for Research on Poverty, Research Working Paper Series \#7, November.

Lurie, Irene. 1974. "Estimates of Tax Rates in the AFDC Program." National Tax Journal 27(1) (March): 93-107.

MacDonald, Maurice. 1985. "The Role of Multiple Benefits in Maintaining the Social Safety Net: The Case of Food Stamps." Journal of Human Resources 20(3) (Summer): 421-436.

Moffitt, Robert. 1979. "Cumulative Effective Tax Rates and Guarantees in Low-Income Transfer Programs." Journal of Human Resources 14(1) (Winter): 122-129.

Moffitt, Robert and Barbara L. Wolfe. 1992. "The Effect of the Medicaid Program on Welfare Participation and Labor Supply." Review of Economics and Statistics 74(4) (November): $615-626$.

Scholz, John Karl. 1994. "The Earned Income Tax Credit: Participation, Compliance, and Antipoverty Effectiveness." National Tax Journal 47(1) (March): 63-85.

U.S. Bureau of the Census. 1992. Statistical Abstract of the United States: 1992. 112th Edition. Washington, D.C.: U.S. Government Printing Office.

U.S. Congress, Committee on Ways and Means. 1990. Overview of Entitlement Programs: 1990 Green Book. Washington, D.C.: U.S. Government Printing Office, June 5.

U.S. Congress, Committee on Ways and Means. 1993. Overview of Entitlement Programs: 1993 Green Book. Washington, D.C.: U.S. Government Printing Office, July 7.

Weinberg, Daniel H. 1985. "Filling the 'Poverty Gap,' Multiple Transfer Program Participation." Journal of Human Resources 20(1) (Winter): 64-79. 
Weinberg, Daniel H. 1987. "Filling the 'Poverty Gap,' 1979-1984." Journal of Human Resources 22(4) (Fall): 563-573.

Wilson, Paul and Robert Cline. 1994. "State Welfare Reform: Integrating Tax Credits and Income Transfers." Paper presented at the 1994 National Tax Symposium, May 24.

Wiseman, Michael. 1993. "Welfare Reform in the States: The Bush Legacy." Focus (newsletter of the Institute for Research on Poverty) 15(1) (Spring): 18-36.

Yin, George K., John Karl Scholz, Jonathan Barry Forman, and Mark J. Mazur. 1994. "Improving the Delivery of Benefits to the Working Poor: Proposals to Reform the Earned Income Tax Credit Program." American Journal of Tax Policy 11(2): 